\title{
放射線照射療法および温熱療法が腸管吻合部と 皮膚縫合部の創傷治癒に与える影響
}

\author{
片 岡 孝小西文雄金澤 曉太郎 \\ 自治医科大学消化器一般外科
}

キーワード：直腸癌の術前治療, 放射線照射療法, 温熱療法, 創傷治癒

は じ め に

大晹癌，とくに直腸癌に対して，放射線照射療 法や温熱療法が術前治療として施行されている1212) 334).これらの術前治療の目的としては，1）原発 巣やリンパ管あるいは転移リンパ節などにおける 癌細胞の viability の低下や消失により局所再発 を抑制すること，2）術野に抢ける癌細胞の im. plantation を防止し局所再発を抑制すること，3） 原発巣を縮小させ手術適応の搪大をはかることな どがあげられる4.

術前治療に扔いて，放射線照射療法に温熱療法 を併用した場合は，1）放射線照射に対して腫湟 が抵抗性を示す低酸素状態において温熱療法の 効果が増強される(5)67)，2）腫韵内にみられるよう な低 $\mathrm{pH}$ 環境において温熱療法の効果が増強さ

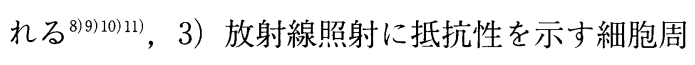
期の $\mathrm{S}$ 期にある腫瘍細胞は温熱療法に対して高感 受性である ${ }^{12} ， 4 ）$ 温熱潦法は放射線照射によっ て障害された腫瑒細胞の回復を阻害する の臨床上好都合な現象が付加されることが期待で きる。

しかし,これらの術前治療が周囲の正常組織に 悪影響を与え, 術後の腸管吻合部あるいは会陰創

1994年10月 3 日受付（依頼原稿）
の創傷治癒を悪化させるならば臨床的に問題であ る. そこで，本稿では放射線照射療法および温熱 療法が創傷治癒に与える影響を著者らの行った実 験の結果をふまえて概説したい。

\section{I ．放射線照射が創傷治痖に 与える影響}

直腸癌に対する術前の放射線照射は，1914 年 に Symondsにより最初に報告された ${ }^{15}$. それ以 来, 直腸癌に対する術前放射線照射について多く の報告がなされている。これらの報告における放 射線照射量はおよそ15 Gy から 60 Gy であるが， 術前照射の効果を期待するには, $40 \mathrm{~Gy}$ 前後が妥 当と考えられる ${ }^{16171718 \text {. }}$.

一般に術前放射線照射療法を施行した場合には， 術後の創傷治癒が悪化するということが指摘され ている ${ }^{192021211}$.

Morgenstern らの実験によれば，術前に $40 \mathrm{~Gy}$ 以上の放射線照射を施行した場合は, 術後の縫合 不全の発生の危険が高くなると報告している19. またStevens らは $50 \mathrm{~Gy}$ の術前放射線照射後, 前方切除術を施行した場合は縫合不全および腸管 の癒着, 腸管の閉塞が高頻度に認められると報告 している ${ }^{20}$. Gerard らは, 直腸癌に対して術前 に 34.5 Gy の放射線照射を施行した場合, Miles 手術における会陰創の創傷治癒は, 手術のみ施行 
a)

Gamma Cell $40\left({ }^{137} \mathrm{Cs}\right)$

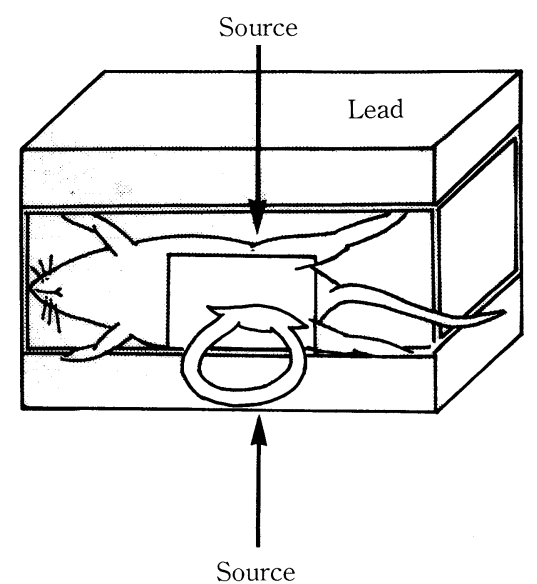

図 1

a ）腸管に対する放射線照射の方法

b)

Gamma Cell $40\left({ }^{137} \mathrm{Cs}\right)$

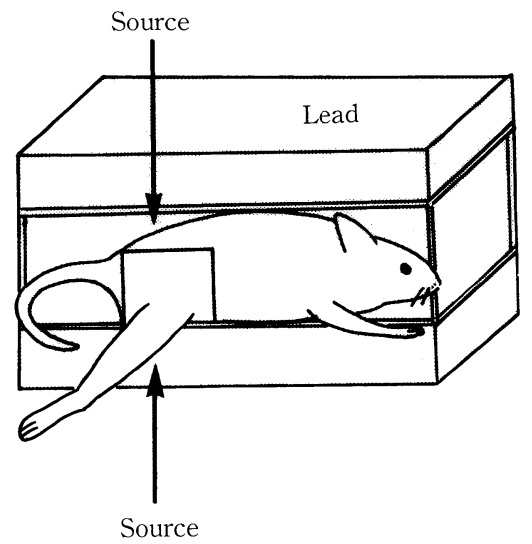

b ）皮膚に対する放射線照射の方法
した群に比べて優位に遷延したと報告している ${ }^{21)}$. 一方，40 Gy の放射線を術前照射しても自動吻合 器による腸管吻合は安全に行えるという実験の報 告もある 22 .

著者らはラットの腸管のみあるいは右後肢の皮 膚のみに放射線照射を施行後, 腸管吻合あるいは 皮虚の切開縫合を施行し, 術後の創傷治癒につい て検討した，放射線照射は ${ }^{137} \mathrm{Cs}$ を線源とするガ ンマーセル 40 （カナダ原子力公社）を用いて 15 Gyを 1 回照射した（R群，図 $1-a, b)$.コント ロール (RC) 群は腸管あるいは右後肢も含めて鉛 板で遮蔽して 15 Gy を照射した. 15 Gy 1 回 照射した場合の効果は, Nominal Standard Dose Equationによれば総線量が $40 \mathrm{~Gy}$ となる分割照 射の効果とほぼ同等と考えられる ${ }^{23)}$.

創傷治瘉の状態は，物理学的指標として腸管吻 合部では耐圧力を，皮膚縫合部では抗張力を測定 し，さらに生化学的指標として腸管吻合部と皮膚 縫合部の hydroxyproline 濃度を測定して評価し た. $15 \mathrm{~Gy}$ の術前照射を行った場合は，物理学的 指標である腸管吻合部の耐圧力あるいは皮虐縫合
部の抗張力，さらに腸管吻合部抒よび皮膚縫合部 の hydroxyproline 濃度からみると放射線照射に より創傷治癒の悪化が認められた ${ }^{24}$ ) (図 $2-a, b$; 図 $3-a, b$ ).

\section{II . 温熱療法が創傷治癒に与 える影響}

温熱による癌の治療は, 紀元前 3000 年頃に Hippocrates が焼却法を行っている. 最初の文献 としては，1866 年にBusch が顔面の肉腫が丹毒 による発熱で消失したことを報告している ${ }^{25}$. 1893 年には Coley が丹毒菌から抽出した Coley's toxin を用いて癌が治癒した症例を報告してい る ${ }^{26)} .1960$ 年後半から温熱の抗腫瘍性に関する研 究の進歩, 加温方法の進歩により, 温熱による癌 治療が臨床に取り入れられるようになった。温熱 療法が単独で施行されることは少ないと考えられ るが，温熱療法が創傷治癒に対してどのような影 響を及ぼすのかについては十分な検討はなされて いない，清水らの実験によれば，ラットの腸管吻 合を行った後に $44^{\circ} \mathrm{C}$ で 30 分間加温しても腸管吻 
a)

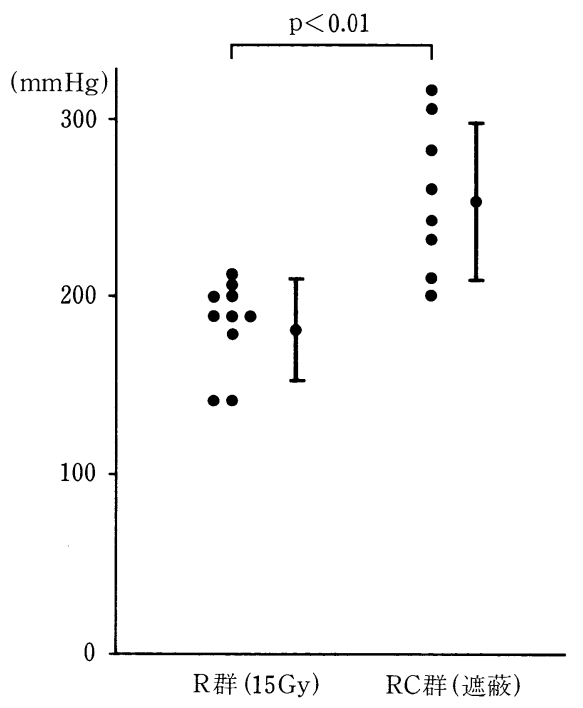

b)

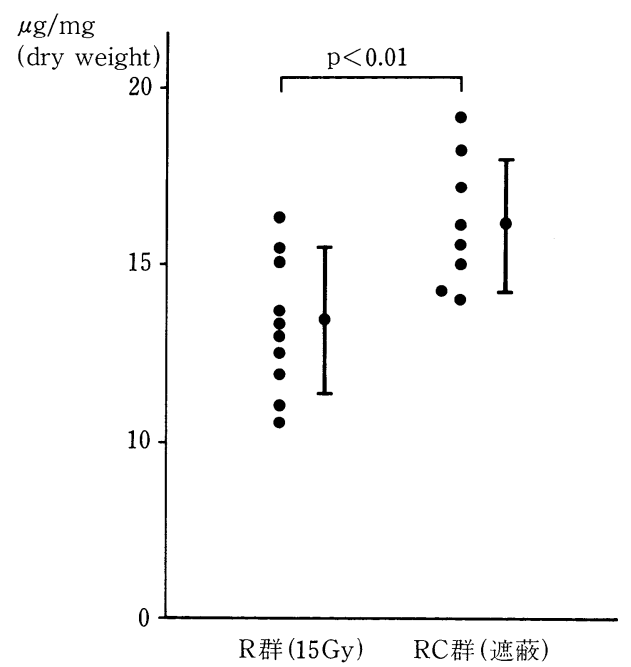

図 2 放射線照射 $(\mathrm{R})$ 群，コントロール $(\mathrm{RC})$ 群の腸管吻合部における a ) 耐圧力および b ) hydroxyproline 濃度

a)

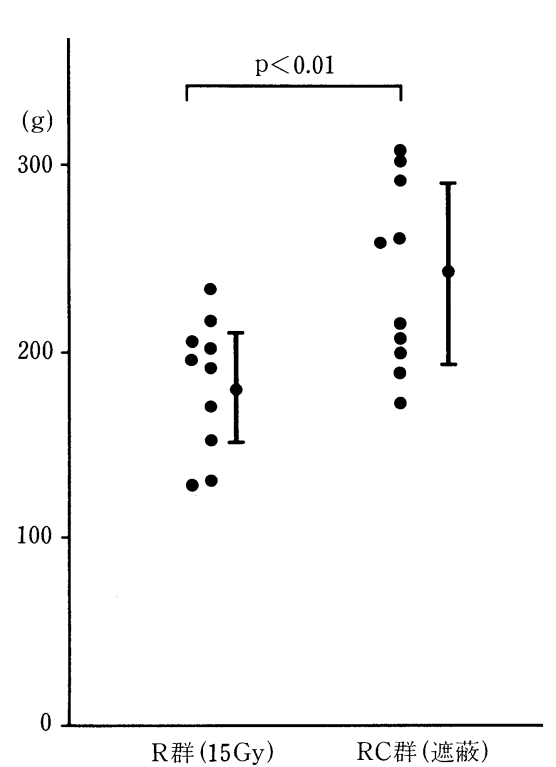

b)

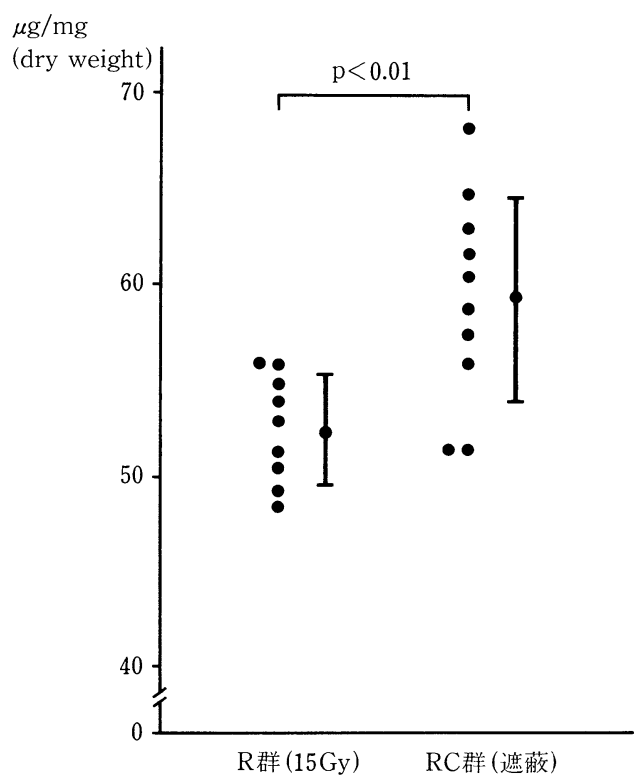

図 3 放射線照射 (R) 群，コントロール（RC）群の皮膚縫合部における

a ）抗張力および b ) hydroxyproline 濃度 
a )

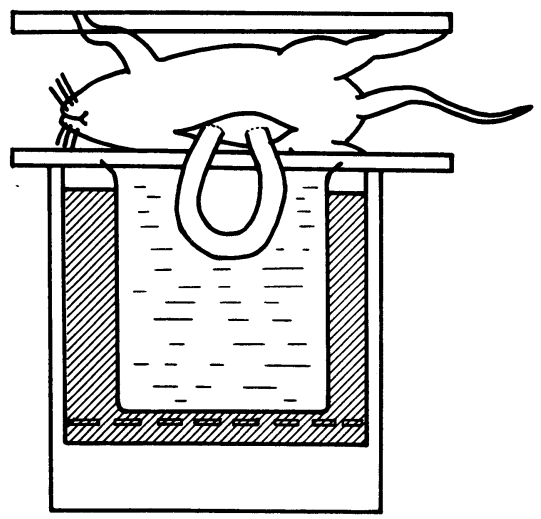

図 4 a ）腸管に対する温熱療法の方法

合部の物理学的強度の低下は認められなかったと 報告している ${ }^{27)}$.

著者らは, ラットの腸管あるいは右後肢の皮膚 を恒温水槽 $\left(\mathrm{LF}-480\right.$, 精度 $\pm 0.05^{\circ} \mathrm{C}$, アドバン ティク社）を用いて $44^{\circ} \mathrm{C}$ で 30 分間加温（HT 群, 図 4 - a, b ) した後, 腸管吻合あるいは皮虚の切 開縫合を施行し, 術後の創傷治癒について検討し た.コントロール (HTC) 群は $37^{\circ} \mathrm{C}$ で 30 分間加 温した。 $44^{\circ} \mathrm{C} て ゙ 30$ 分間加温した場合の効果は, 対象となる細胞の種類によって異なるが，Fajardo らによれば EMT-6 腫瘍細胞を移植したマウ スを用いた実験において $44^{\circ} \mathrm{C} て ゙ 30$ 分間の加温を 施行した場合，48 時間後の細胞数はコントロー ルの $0.0003 \%$ になると報告している ${ }^{28)}$.

$44^{\circ} \mathrm{C}$ で 30 分間加温した場合には，物理学的指 標である腸管吻合部の耐圧力あるいは皮膚縫合部 の抗張力および生化学的指標である hydroxyproline 濃度からみると術後の腸管吻合部抒よび皮膚 縫合部の創傷治癒の悪化は認められなかった ${ }^{24}$.

\section{III. 放射線照射と温熱療法を 併用した場合の創傷治癒 に与える影響}

温熱療法は単独で施行されることは少なく, 1990年には温熱療法が放射線照射療法との併用に b )

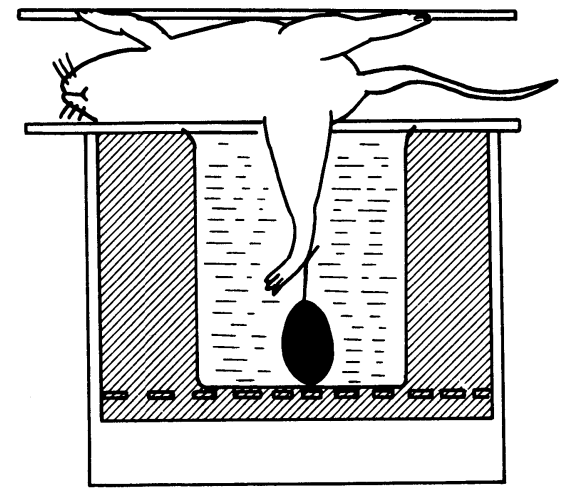

b ）皮膚に対する温熱療法の方法

限り健康保険の適応になった，直腸癌の術前治療 は必然的に時間的制約を受けざるを得ないが，副 作用がなく，より腫瘍に対して効果のある術前治 療が行えれば理想的である。放射線照射に温熱療 法を併用した場合は，前述したように癌治療にお いて相補的な効果が期待でき，放射線照射に温熱 療法を併用することにり, 単独で放射線照射を施 行した場合に比べて，より腫瘍組織に対して効果 があると考えられる。 そして，創傷治癒に対して は単に放射線の照射量を増加させた場合と比較し て，温熱療法を併用することにより悪影響を少な くすすることができれば，臨床的意義が一段と大き くなると考えられる．現在までに放射線照射に温 熱療法を併用した際の創傷治癒の問題を系統的に 扱った研究はない.

そこで，著者らはラットの腸管のみあるいは右 後肢の皮膚のみに $15 \mathrm{~Gy}$ を 1 回照射した 1 時間 後に $44^{\circ} \mathrm{C}$ て 30 分間加温 (R+HT 群) し，腸管 吻合あるいは皮膚の切開縫合を施行して, 術後の 創傷治瘉について検討した。コントロール（RC +HTC）群は，腸管あるいは右後肢の皮虐も含め て鉛板で遮蔽して $15 \mathrm{~Gy}$ を照射した 1 時間後に $37^{\circ} \mathrm{C}$ で 30 分間加温した。放射線照射と温熱療法 を併用した場合には，物理学的指標である腸管吻 合部の耐圧力あるいは皮膚縫合部の抗張力および 
a)

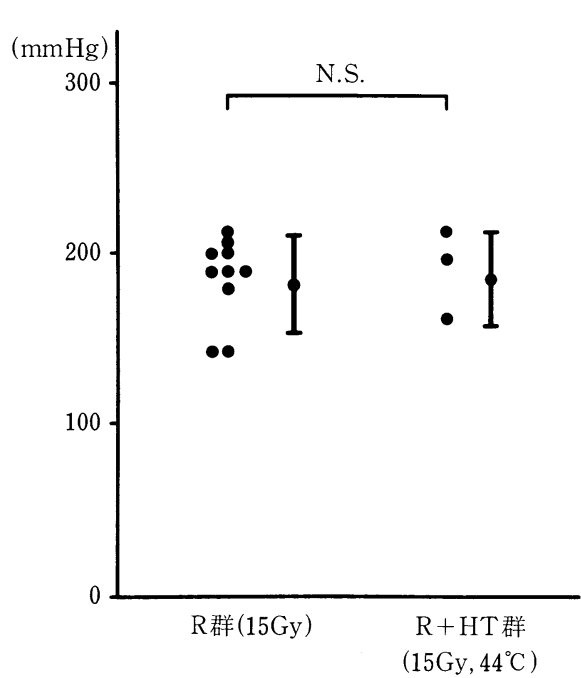

b)

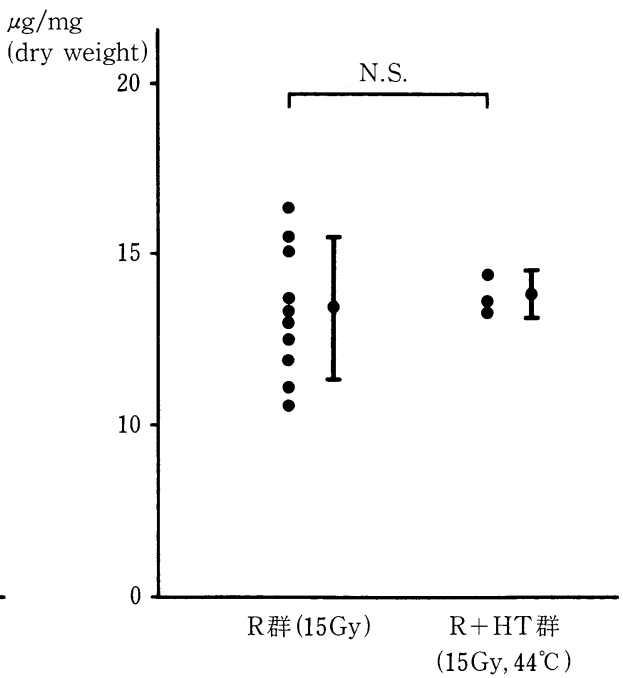

図 5 放射線照射 (R) 群, 放射線・温熱療法併用 (R+HT) 群の腸管吻合部における a ) 耐圧力および $\quad$ b ) hydroxyproline 濃度

a)

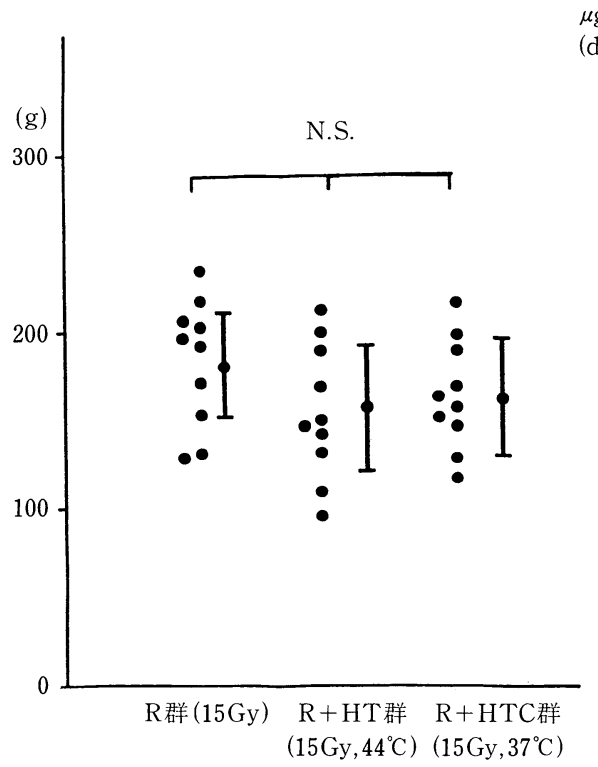

b)

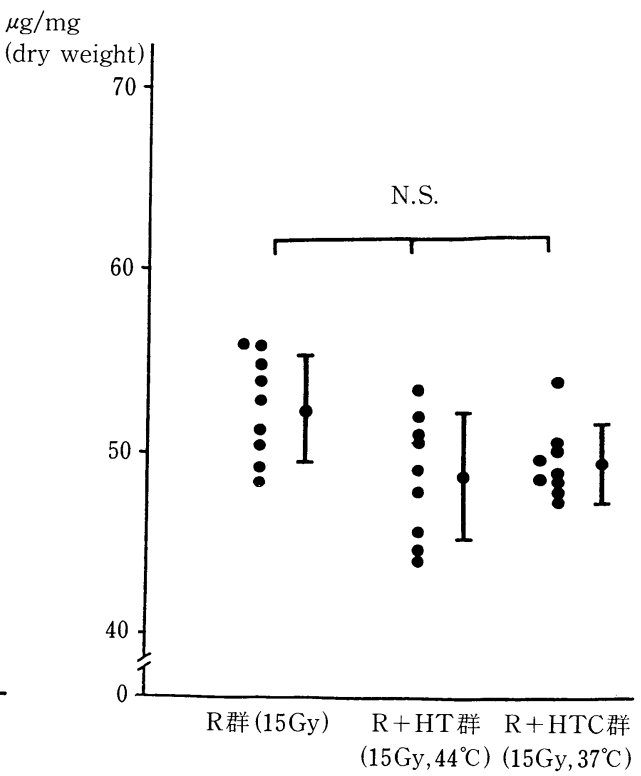

図 6 放射線照射 (R) 群，放射線・温熱療法併用 $(\mathrm{R}+\mathrm{HT})$ 群，放射線照射・温熱療法 のコントロール (HTC 群) 併用 $(\mathrm{R}+\mathrm{HTC})$ 群の皮虐縫合部に抢ける a ) 抗張力 および b ) hydroxyproline 濃度 
生化学的指標である hydroxyproline 濃度からみ るとコントロール群に比べて創傷治癒の悪化が認 められた，腸管吻合部に関しては，放射線照射と 温熱療法を併用した場合, 腸管の癒着が高度にみ られ実験に供することができなかったラットが多 く, 有効匹数が少なくなり統計学的意義は少ない と考えられるが，放射線照射と温熱療法を併用し て施行しても放射線照射を単独で施行した場合と 比べて, 腸管吻合部および皮膚縫合部の創傷治癒 をさらに悪化させることはなかった（図 5 - a, b ; 図 $6-\mathrm{a}, \mathrm{b})^{24)}$.

\section{お わ り に}

放射線照射療法および温熱療法が，腸管吻合部 と皮膚縫合部の創傷治癒に与える影響について実 験結果を中心に論述した.

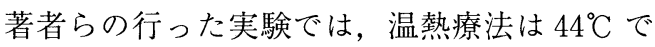
30 分間の加温を施行したが，これが通常臨床で 行われている約 $42^{\circ} \mathrm{C}$ で50-60 分の加温を 3-4 日 に 1 度の頻度で施行する方法と比べて, 腫瘍に対 してどの程度の効果を有するのかは不明である. しかし, 実験的に $44^{\circ} \mathrm{C} て ゙ 30$ 分間の加温で腫瘍組 織に対する効果は十分期待できると思われる ${ }^{25}$. 実験的なデータではあるが, 今回の結果からは腫 瘍に対して壊死効果のある温度と時間の温熱療法 を単独で施行した場合には創傷治癒に対する明ら かな悪影響は認められなかった。また放射線照射 と温熱療法を併用して施行しても, 放射線照射単 独の場合と比べて創傷治瘉の悪化傾向は認められ なかった。以上より，適度の温熱療法であれば放 射線照射療法に併用して施行しても創傷治癒の障 害をさらに増悪させることは少ないであろうと考 えられたが，今後さらに臨床的に検討を行ってい くことが必要と思われる.

\section{文献}

1) Berdov, B. A., Menteshasvili, G. Z.: Thermoradiotherapy of patients with locally advanced carcinoma of the rectum. Int. J. Hyperthermia. 6: 881-890, 1990.

2) Korenaga, D., Matsushima, T., Adachi, Y. et al:
Preoperative hyperthermia combined with chemotherapy and radiotherapy for patients with rectal carcinoma may prevent early local pelvic recurrence. Int. J. Colorectal. Disease. 7: 206-209, 1992.

3）小西文雄, 古田一裕, 斉藤幸夫他：直腸癌術前放 射線温熱化学併用療法における温熱治療付加によ る効果. 日消外会誌, 27: 789-786, 1994.

4) Higgins, G. A. Jr., Conn, J. H., Jordan, P. H. et al.: Preoperative radiotherapy for colorectal cancer. Ann. Surg. 181: 624-631, 1975.

5) Suit, H. D., Gerweck, L. E.: Potential for hyperther mia and radiation therapy. Cancer Res. 39: 22902298, 1979.

6) Gerweck, L. E., Gillette, L. E., Dewey, W. C.: Killing of Chinese hamster cells in vitro by heating under hypoxic or aerobic conditions. Eur. J. Cancer. 10: 691-693, 1974.

7) Nielsen, O. S.: Effect of fractionated hyperthermia on hypoxic cells in vitro. Int. J. Radiat. Biol. 39, 73-82, 1981.

8) Gerweck, L. E., Rottinger, E.: Enhancement of mammalian cell sensitivity to hyperthermia by $\mathrm{pH}$ alteration. Radiat. Res. 67: 508-511, 1976.

9) Overgaad, J.: Influence of extracellular $\mathrm{pH}$ on the viability and morphology of tumor cells exposed to hyperthermia. J. Natl. Cancer Inst. 56: 1243-1250, 1976.

10) Gerweck, L. E.: Modification of cell lethality at elevated temperatures: The $\mathrm{pH}$ effect. Radiat. Res. 70: 224-235, 1977.

11) Holahan, E. V., Highfield, D. P., Holahan, P. K., et al: Hyperthermic killing and hyperthermic radiosensitization in Chinese hamster ovary cells: Effects of $\mathrm{pH}$ and thermal tolerance. Radiat. Res. 97: 108-131, 1984.

12) Westra, A., Dewey, W. C. : Variation in sensitivity to heat shock during the cell-cycle of Chinese hamster cells in vitro. Int. J. Radiat. Biol. 19: 467-477, 1971.

13) Leith, J. T., Miller, R. C., Gerner, E. W. et al.: Hyperthermic potentiation: Biological aspects and application to radiation therapy. Cancer. 39: 766779, 1977.

14) Suit, H. D., Phil, D.: Hyperthermic effects of animal tissues. Radiology. 123: 483-487, 1977.

15) Symonds, C. J.: Cancer of rectum: Excision after application of radium. Proc. R. Soc. Med. 7: 152, 1914.

16) 安富正幸: 消化器癌の術前, 術中, 術後照射一手 術と放射線の最適併用一直腸癌, 概説. 医学書院, 199-206, 1992.

17）北川俊夫，伊藤一二，広田映五他：直腸癌の術前 照射. 第 1 報. 照射効果に関する検討. 日癌治療 
会誌, 10: 28-33，1975.

18）更科廣實, 轟健, 折居和雄他：直腸癌術前照射に おける局注併用療法の治療効果. 日外会誌. 88: 569-576, 1987.

19) Morgenstern, L., Sanders, G., Wahlstrom, E. et al.: Effect of preoperative irradiation on healing of low colorectal anastomoses. Am. J. Surg. 147: 246-249, 1984.

20) Stevens, K. R., Fletcher, W. S., Allen, C. V.: Anterior resection and primary anastomosis following high dode preoperative irradiation for adenocarcinoma of the recto-sigmoid. Cancer, 41: 2065-2071, 1978.

21) Gerard, A., Berrod, J. L., Pene, F. et al.: Preoperative radiotherapy and radical surgery as combined treatment in rectal cancer. Recent results. Cancer Res. 110: 130-133, 1988.

22) Bubrick, M. P., Rolfsmeyer, E. S., Schauer, R. M. et al.: Effects of high dose and low-dose preoperative on low anterior anastomoses in dogs. Dis. Colon
Rectum. 25: 406-415, 1982

23) Ellis, F.: Fractionation in radiotherapy. Mod Trends Radiotherapy. 1: 34-51, 1967.

24）片岡孝，小西文雄 : 放射線照射および温熱療法が 腸管吻合部と皮膚縫合部の創傷治癒に与える影響 に関する実験的検討。日本大腸肛門病会誌。47: 295-307, 1994.

25) Bush, W.: Über den Einflüss welchen heftigere Erysipelen züweilen auf organisierte Neubidungen ausuben. Verhandel Naturh Preuss Phein Westphal. 23: 28-30, 1866.

26) Coley, W.: The treatment of malignant tumors by repeated inoculation of erysipers-with a report of ten original cases. Am. J. Med. Sci. 105: 487-511, 1893.

27) Shimzu, T., Maeta, M., Koga, S.: Influence of local hyperthermia on the healing of small intestinal anastomoses in the rat. Br. J. Surg. 78: 57-59, 1991.

28) Fajardo, L. F., Egbert, B., Marmor, J. et al: Effects of hyperthermia in a malignant tumor. Cancer. 45: 613-623, 1980. 


\title{
Influence of Irradiation and Hyperthermia on the Wound Healing of the Intestinal Anastomosis and the Skin Suture in Rat
}

\author{
Takashi Kataoka, Fumio Konishi and Kyotaro Kanazawa \\ Depertment of Surgery, Jichi Medical School
}

\section{Summary:}

The influence of irradiation and/or hyperthermia on the wound healing in the rats was studied. In this study, an exteriorized segment of the small intestine or the skin of the right foot was exposed to single doses of irradiation (15Gy), local hyperthermia $\left(44^{\circ} \mathrm{C}, 30\right.$ minutes), or irradiation plus hyperthermia. After the treatment, intestinal anastomosis or skin suture was performed. The wound healing was assessed by the bursting pressure of the anastomosis, by the tensile strength of suture of the skin, by the hydroxyproline concentration of the tissue around the anastomosis or the skin suture. The wound healing was significantly deteriorated in the group of irradiation. On the other hand, there was no difference in wound healing between the group of hyperthermia and the control group. In the group of combined irradiation and hyperthermia, depressed wound healing was observed. However in this group further deterioration of wound healing was not observed comparing to the irradiation group. It was concluded that under the conditions of this experimental model, hyperthermia did not cause any significant deterioration of wound healing of the intestinal anastomosis and the skin suture.

Key Words: Preoperative treatment of rectal carcinoma, Radiation therapy, Hyperthermia, Wound healing 